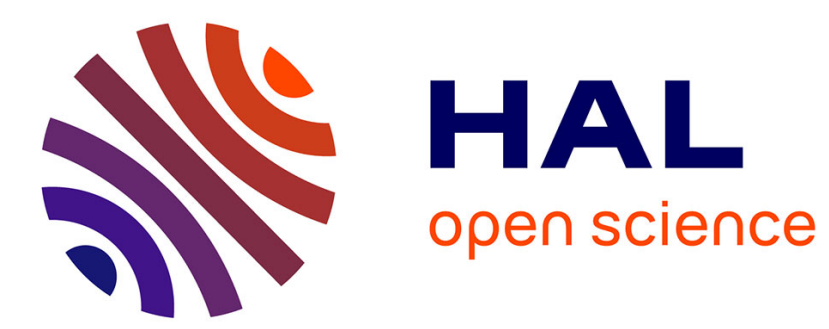

\title{
Urban Sprawl: is there a French case?
}

Denise Pumain

\section{To cite this version:}

Denise Pumain. Urban Sprawl: is there a French case?. Richardson H.W., Bae C.C. Urban Sprawl in

Western Europe and the United States., Ashgate, pp.137-157, 2004. halshs-00000479

\section{HAL Id: halshs-00000479 \\ https://shs.hal.science/halshs-00000479}

Submitted on 2 Jul 2003

HAL is a multi-disciplinary open access archive for the deposit and dissemination of scientific research documents, whether they are published or not. The documents may come from teaching and research institutions in France or abroad, or from public or private research centers.
L'archive ouverte pluridisciplinaire HAL, est destinée au dépôt et à la diffusion de documents scientifiques de niveau recherche, publiés ou non, émanant des établissements d'enseignement et de recherche français ou étrangers, des laboratoires publics ou privés. 


\title{
Urban Sprawl: Is There a French Case?
}

\author{
Denise Pumain
}

\section{Introduction}

Urban sprawl has become established in France with original characteristics that could be summed up as the result of the intermediate position of the country between Northern and Southern Europe. From this situation, several paradoxes emerge: although the most intense phase of the process of urban sprawl, from the 1970s to the beginning of the 1980s, was rather late in comparison with other countries of Northern Europe, the process has been strongly established in the country, more than in Spain and even in Italy, for example. The French situation is nonetheless quite representative of the collective European experience, favoring a combination of the advantages of compact cities and those of more widely dispersed settlements. Thus, in spite of its strength, urban sprawl in France does not emerge as the expression of an 'anti-urban' ideology. The benefits of an attachment to city centers and to the urbanity inherited from the Latin culture are real. Even if the rural heritage of France marked a whole generation of adults (half of the population was still rural in 1950), and can explain a deep attachment to the countryside, urban heritage continues to have strong symbolic and economic importance in France. The evolution of real estate and property values, as well as the very central location of work and of most service bears witness to this.

The search for a form of urban development that would be adapted to European social, political and cultural practices is expressed in the orientations defined by the European Union (European Spatial Planning Development Program, 1999). The recommendations in this document move in the direction of an urban development of a polycentric type, and involve partnerships between city and countryside at different levels of activity. It is evident that the efficacy of the planned policies depends on a good knowledge of contemporary trends in urbanization, given the diversity of the urban systems and the variety of forms of urban government from country to country (SPESP, 2001). We are reminded here of the specific nature of the political and institutional setting of urban development in France. Without being as interventionist in urban planning as Holland or Sweden, the French state has certainly played an important role in the extension of the cities, through its policies related to housing and transportation. The spatial fragmentation of the territory into very small communes is in part compensated for by the existence of general planning approaches, and by the emergence of cooperation between municipalities. The spatial extension of the cities has therefore become a political question, which belongs to the issue of the durability of development, at the same time that it has given rise to new definitions of urbanized space.

\section{New Definitions of Urbanized Space}

Because the growth of cities is brought about not only through an increase in the population within fixed limits, but also through spatial expansion, it is always difficult to measure. International comparisons are still complicated by the differences in ways of defining the urban population and demarcating city limits in the different countries (Pumain, Saint-Julien, 1991).

From Morphological 'Agglomérations' to 'Aires Urbaines'

French territorial divisions (NUTS 5 level of local units) are among the smallest in Europe $\left(1.5 \mathrm{~km}^{2}\right.$ and 1600 inhabitants on average, but half of the communes have fewer than 400 inhabitants). The principle of defining the multi-communal statistical urban units was therefore accepted very early. The urban agglomeration, created in 1954, was defined on the basis of the morphological criterion of the continuity of what was built (less than $200 \mathrm{~m}$ between two edifices), and the population threshold of 2,000 inhabitants. It includes the center of the commune, 
which corresponds to the most populated commune of the agglomeration (usually the historic center), and the communes of the suburbs.

In 1996, the 'aires urbaines' replaced the Z. P. I. U. (Zones of Urban and Industrial Settlements), which were considered to be too extensive (they concentrated three quarters of the communes and especially $96 \%$ of the French population in 1990). An 'aire urbaine' is composed of an urban center and a surrounding urban ring. Urban poles are urban agglomerations that number more than 5,000 jobs. Formed of successive communes, the outer urban ring brings together communes in which at least $40 \%$ of the active members work in the urban center or in a secondary center that is already attached to the urban center by means of this criterion. 'Espace à Dominante Urbain'e (space with a dominant urban character) includes 'aires urbaines', but also 'communes multipolarisée's, which send at least $40 \%$ of their population into several urban centers without any one of these centers reaching this threshold. The map on figure 1 represents in dark color the urbanized areas which constitute the central part of the 'aires urbaines' whereas the spatial extension of their outer rings appear in light color.

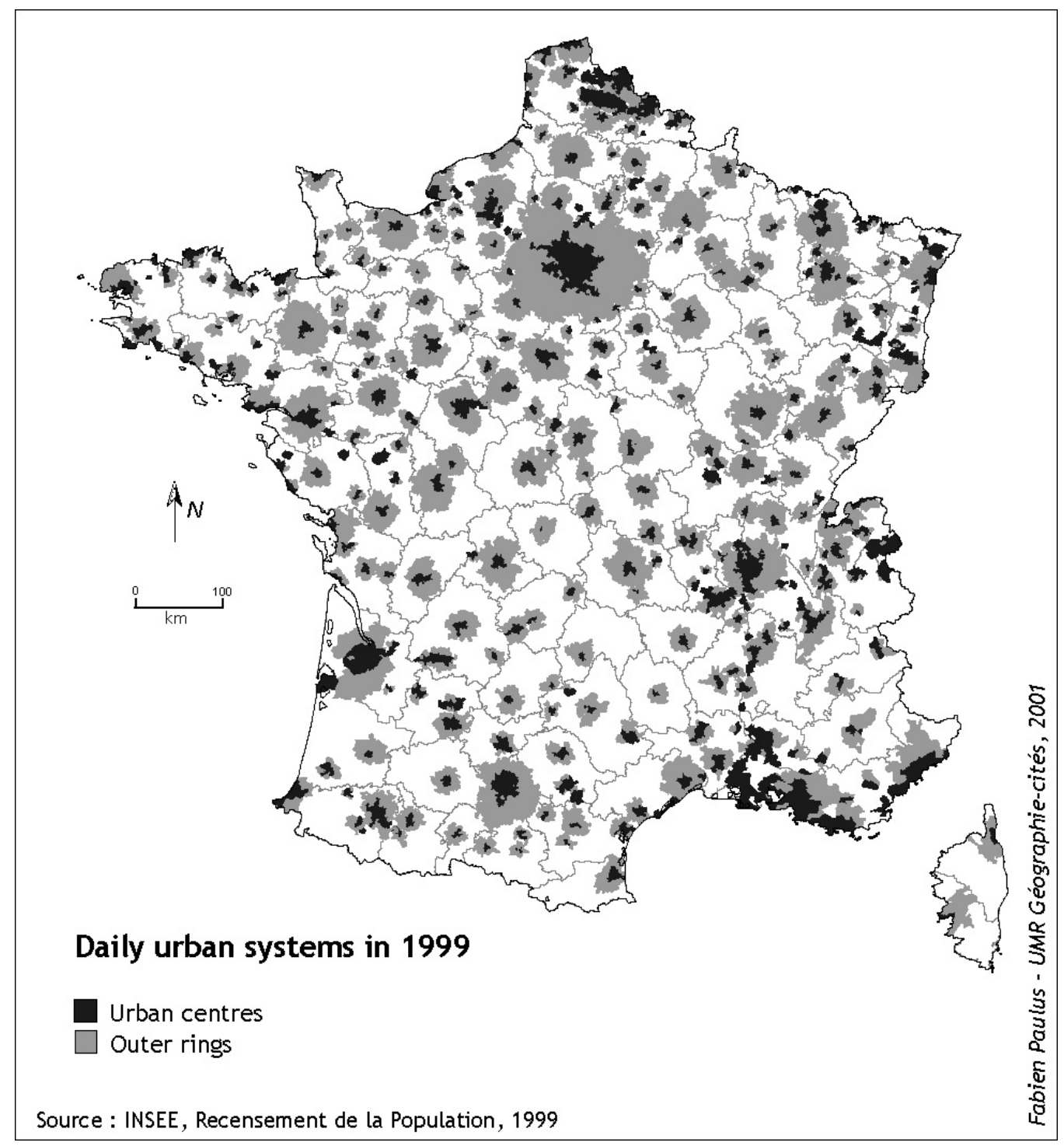

Figure 1: Urban centers and outer rings of the French 'aires urbaines' in 1999 


\section{The Extent of Urbanized Space}

The database constructed by Ph. Julien (2001) and analyzed by F. Paulus (Paulus, Pumain, 2002), reconstructs for the censuses from before 1990 the different demarcations arrived at for urban areas. The definitions of the 'agglomérations' and 'aires urbaines' provide two complementary pictures of French urbanization (Table 1). In the census of 1999, 1,995 agglomérations were counted, spreading across around 6,000 communes, that is, 44.2 million inhabitants, and a surface area of $100,000 \mathrm{~km}^{2}$. Grouping $75.5 \%$ of the French population in $18 \%$ of the territory, with an average density of 442 inhabitants per $\mathrm{km}^{2}$, the agglomérations constitute dense nuclei of urbanization. The aires urbaines are at one and the same time less numerous and more spread out: these 354 pools of work and daily life centered on the largest pockets of work include a somewhat larger population (45 million inhabitants, that is, $77 \%$ of the French population), but more particularly, spread out over a much wider surface area (13,900 communes, $176,000 \mathrm{~km}^{2}$, that is, $32 \%$ of the territory). The average density of these zones under a strong urban influence is only 250 inhabitants per $\mathrm{km}^{2}$, that is, only twice the average density of the French population.

Table 1: The Development of Urbanization in France According to Two Definitions (1968-1999)

\begin{tabular}{|c|c|c|c|c|c|c|}
\hline Urban Zoning & $\begin{array}{l}\text { Demographic } \\
\text { and spatial } \\
\text { characteristics }\end{array}$ & 1968 & 1975 & 1982 & 1990 & 1999 \\
\hline $\begin{array}{l}\text { Agglomératio } \\
\text { ns }\end{array}$ & $\begin{array}{l}\text { Number of } \\
\text { entities } \\
\text { Nb. of } \\
\text { communes } \\
\text { Surface }\left(\mathbf{k m}^{2}\right) \\
\text { Population } \\
\\
\text { Average } \\
\text { Density (inhab. } \\
\text { per } \mathbf{k m}^{2} \text { ) }\end{array}$ & $\begin{array}{r}1520 \\
3958 \\
\\
68827 \\
34817 \\
487 \\
506\end{array}$ & $\begin{array}{r}1642 \\
4450 \\
\\
76227 \\
38333 \\
592 \\
503\end{array}$ & $\begin{array}{r}1781 \\
4879 \\
83323 \\
39850 \\
831 \\
478\end{array}$ & $\begin{array}{r}1890 \\
5300 \\
\\
89642 \\
41894 \\
167 \\
467\end{array}$ & $\begin{array}{r}1995 \\
5956 \\
\\
100052 \\
44201 \\
027 \\
442\end{array}$ \\
\hline $\begin{array}{c}\text { Aires } \\
\text { urbaines }\end{array}$ & $\begin{array}{l}\text { Number of } \\
\text { entities } \\
\mathrm{Nb} \text {. of } \\
\text { communes } \\
\text { Surface }\left(\mathrm{km}^{2}\right) \\
\text { Population } \\
\\
\text { Average } \\
\text { Density (inhab. } \\
\text { per } \mathbf{k m}^{2} \text { ) }\end{array}$ & $\begin{array}{r}319 \\
3502 \\
\\
42733 \\
30106 \\
017 \\
705\end{array}$ & $\begin{array}{r}347 \\
\\
6064 \\
\\
71756 \\
34918 \\
289 \\
487\end{array}$ & $\begin{array}{r}359 \\
8313 \\
\\
100218 \\
37725 \\
248 \\
376\end{array}$ & $\begin{array}{r}361 \\
10687 \\
\\
132090 \\
41277 \\
858 \\
312\end{array}$ & $\begin{array}{r}354 \\
13908 \\
175997 \\
45052 \\
901 \\
256\end{array}$ \\
\hline
\end{tabular}

According to: F. Paulus (2002). Sources : INSEE -Censuses of the population and Ph. Julien (2001)

\section{Spreading Out. The Process: a Wave of Urbanization and Peri-Urbanization}

The present configuration of population growth results from a cycle of urbanization that has profoundly transformed the French landscape for fifty years. A high rate of demographic and economic growth, accompanied by a strong rural exodus, was expressed in the beginning by a very rapid growth in the population of the cities (on the order of $2 \%$ per year between the years 1950 and 1975), and up until the 1960s, by an increase in urban densities. Because of the decrease in fertility beginning in 1964, and the gradual drying up of the reserves of the rural population, the growth in urban population slowed down, which is reflected in average annual rates of less than $1 \%$, and a change in composition, as natural growth began to outnumber the contribution from migrations. 
But in particular, the most spectacular novelty in the ways the cities have been expanding since the 1970s is in geographical dispersion. This process results at one and the same time in a transfer of the growth of the cities towards more remote rural peripheries, and a spacing out of populations that has tended to lower urban densities.

\section{Peri-Urbanization}

Since the 1960s, the growth of the cities has been projected quite far beyond urban agglomérations, dynamizing rural districts situated at their periphery, in zones that were no longer being built as a continuation of the pre-existing urban fabric, but which possessed or established daily and close functional ties with the agglomération and its city center. The map of figure 2 illustrates this tremendous spatial expansion by comparing the actual delimitation of the aires urbaines with the one, much more restricted, that they would have had in 1968.

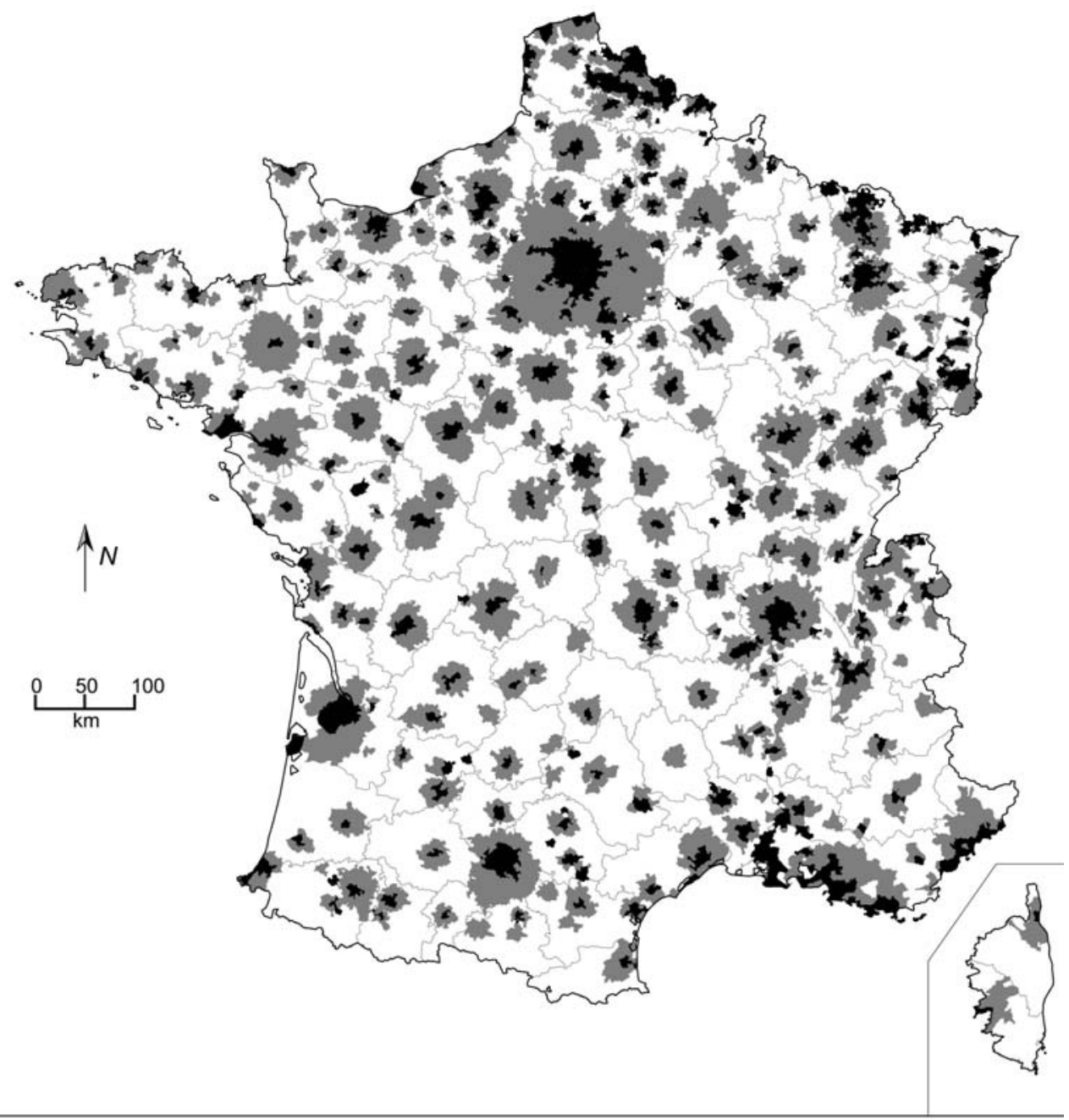

Extension of daily urban systems in 1968

Extension of daily urban systems in 1999

Source : INSEE, Recensements de la Population

Fabien Paulus - UMR Géographie-cités, 2001

\section{Figure 2 Spatial extension of 'aires urbaines' from 1968 to 1999}

When we measure this spatial extension of urbanization in the framework of the aires urbaines, it takes on its full significance: between 1968 and 1999, the surface area 'urbanized' in this way was multiplied by 5, the number of urban communes multiplied by 4 , while the total population increased by only $50 \%$. While the surface area of the 
agglomérations increased by only $1.2 \%$ a year during this whole period, those of the aires urbaines grew in much more significant proportions: $4.7 \%$ per year (Table 2). In both cases, the year 1975 marked the beginning of a slowdown in this process: since that date, the aires urbaines have continued to spread out in surface area, but the present rate is no more than $3.2 \%$ per year, while that of the agglomérations, after a drop, remains on the order of $1.2 \%$ per year.

Table 2: Average Annual Rates of Variation in Urban Expansion (\%)

\begin{tabular}{|c|c|c|c|c|c|c|}
\hline $\begin{array}{c}\text { Urban } \\
\text { Zoning }\end{array}$ & $\begin{array}{l}\text { Demographic } \\
\text { and spatial } \\
\text { characteristics }\end{array}$ & $\begin{array}{l}1968- \\
1975\end{array}$ & $\begin{array}{l}1975- \\
1982\end{array}$ & $\begin{array}{l}1982- \\
1990\end{array}$ & $\begin{array}{l}1990- \\
1999\end{array}$ & $\begin{array}{l}1968- \\
1999 \\
\end{array}$ \\
\hline Agglomérations & $\begin{array}{l}\text { Number of } \\
\text { entities } \\
\text { Nb. of } \\
\text { communes } \\
\text { Surface }\left(\mathrm{km}^{2}\right) \\
\text { Population } \\
\text { Average } \\
\text { Density (inhab. } \\
\text { per } \mathbf{k m}^{2} \text { ) }\end{array}$ & $\begin{array}{r}1,11 \\
1,69 \\
1,47 \\
1,38 \\
-0,08\end{array}$ & $\begin{array}{r}1,17 \\
1,32 \\
1,28 \\
0,56 \\
-0,71\end{array}$ & $\begin{array}{r}0,75 \\
1,04 \\
\\
0,92 \\
0,63 \\
-0,29\end{array}$ & $\begin{array}{r}0,60 \\
1,31 \\
\\
1,23 \\
0,60 \\
-0,62\end{array}$ & $\begin{array}{r}0,88 \\
1,33 \\
1,21 \\
0,77 \\
-0,44\end{array}$ \\
\hline $\begin{array}{c}\text { Aires } \\
\text { urbaines }\end{array}$ & \begin{tabular}{|l} 
Number of \\
entities \\
Nb. of \\
communes \\
Surface $\left(\mathbf{k m}^{2}\right)$ \\
Population \\
Average \\
Density (inhab. \\
per $\mathbf{k m}^{2}$ ) \\
\end{tabular} & $\begin{array}{r}1,21 \\
8,16 \\
\\
7,69 \\
2,14 \\
-5,15\end{array}$ & $\begin{array}{r}0,49 \\
4,61 \\
4,89 \\
1,11 \\
-3,60\end{array}$ & $\begin{array}{r}0,07 \\
3,19 \\
\\
3,51 \\
1,13 \\
-2,30\end{array}$ & $\begin{array}{r}-0,22 \\
2,97 \\
\\
3,24 \\
0,98 \\
-2,19\end{array}$ & $\begin{array}{r}0,34 \\
4,55 \\
4,67 \\
1,31 \\
-3,21\end{array}$ \\
\hline $\begin{array}{l}\text { Metropolitan } \\
\text { France }\end{array}$ & Population & 0,81 & 0,47 & 0,52 & 0,37 & 0,53 \\
\hline
\end{tabular}

According to: F. Paulus (2002). Sources : INSEE - Censuses of the population and Ph. Julien (2001)

The spatial extension of the cities was thus considerably more rapid than the growth of the population they welcomed. On the periphery, the forms of urbanization were more and more diluted on the borders of the periurbanization zones, while to the contrary, a certain condensation was produced in the first rings of the periphery, those that are the closest to former suburbs, and which become integral parts of the agglomérations. In both cases, the process of peri-urbanization is combined with a process of reduction in the density of the resident population in the urbanized zones, which helps to explain the urban spatial diffusion.

\section{The Process of Reduction in Population Density}

Whether measured in the setting of agglomérations or of aires urbaines, the densities of urban population have not ceased to decline since 1968 (Table 2). This decrease is slow, around $0.4 \%$ per year in the agglomérations, and irregular, with two phases of greater intensity near the end of the 1970s and the 1990s. In the setting of the aires urbaines, the strong initial density particularly reflects the fact that at that time they involved the largest cities (on an average, the densities rise with the size of the cities), and the rapid reduction in density reveals the gradual integration of smaller urban centres, and especially the numerous sparsely-populated rural communes.

The contrast in population density between the city centers and the peripheries has diminished in all the agglomérations of more than 20,000 inhabitants. However, in no city has a reversal of the center-periphery gradient been observed, either in population density or in terms of real estate and property values. 
The process of spacing out is also measured by the inequalities in demographic growth observed in the various sectors of the aires urbaines according to present boundaries (Table 3). These illustrate an undulating spread in growth, initially greatest in the suburbs, then in the peri-urban rings beginning in 1975-1982, when the central communes were beginning a demographic decline. During the last decade, with the reduction in the general growth of the urban population, there has been a tendency for the intensities of growth in all the component parts of the urban population to converge.

Table 3: Demographic Changes in the City Centers, Suburbs and Peri-Urban Rings (1968-1999, 1999 Boundaries)

\begin{tabular}{|ccccc|}
\hline Components of Aires Urbaines & \multicolumn{5}{c|}{ Average annual rate of variation in population } \\
& \multicolumn{5}{c}{ (\%) } & $1968-$ & $1975-$ & $1982-$ & $1990-1999$ \\
City centre & 1975 & 1982 & 1990 & \\
Suburbs & 0.29 & -0.44 & -0.10 & 0.12 \\
Peri-Urban Ring & 2.13 & 0.94 & 0.87 & 0.43 \\
Total of the Aire Urbaine & 1.40 & 2.24 & 1.66 & 0.97 \\
& 1.19 & 0.58 & 0.64 & 0.42 \\
\hline
\end{tabular}

According to : F. Paulus (2002). Sources :Censuses of the population, INSEE

The spacing out of the urban populations has been perpetuated by the pattern of residential migrations, which have produced a centrifugal dynamic of populations, from the center towards the suburbs and the peri-urban ring. The peri-urban sector thus owes its dynamism to the populations that have chosen to establish themselves there. It is the opposite of the rise in births that made it possible to maintain the population of the centers, which a significant number of inhabitants were deciding to leave.

In total, the segment of the population of the aires urbaines living in the central communes has diminished at a regular rate, dropping from $46 \%$ in 1968 to $37 \%$ in 1999, while that of the suburbs has become preponderant, progressing from 38 to $42 \%$, and that of the peri-urban rings has grown from 16 to $21 \%$. The type of life we could call 'rurban' involves only about a fifth of the urban populations (figure 3).

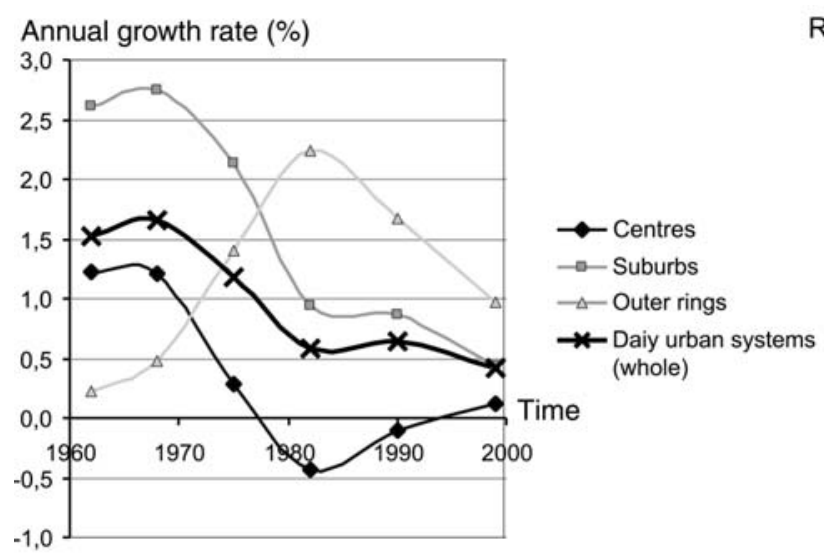

Source : INSEE, Recensements de la population

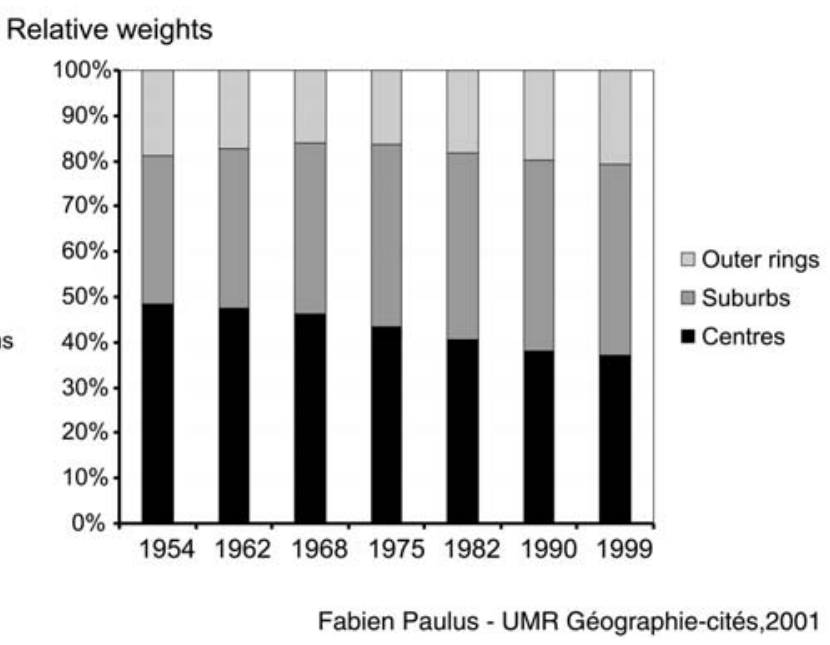

Figure 3 The evolution of population growth rates according to the components of 'aires urbaines' 1968-99 
Jobs Spread Out Less Rapidly than Residences

Job locations still remain highly concentrated in the central sections of the agglomerations (Lainé, 2000): in 1999, more than $41 \%$ of jobs were located in the central communes, and $30 \%$ in suburban communes. Admittedly, the number of jobs located in the central communes dropped by $1.3 \%$ per year between 1990 and 1999, but it continued to rise in the suburbs much more significantly than in the peri-urban ring (1.3\% as opposed to $0.4 \%)$. Today fewer than $10 \%$ of jobs are established in the peri-urban rings, while the number of jobs in the rural communes $(16 \%$ of the total) continues to fall (those of the communes multipolarisées remain proportionately stable, that is, at 3\%).

Admittedly, in the periphery of the largest cities, centers for secondary jobs have emerged, either by the absorption of preexisting urban centers, or by the implantation of new activities near transportation infrastructures (airports, motorway intersections), or in new zones of urbanization (La Défense, west of Paris, the new towns, or again the technopolitan zones in most of the regional metropolises). The growth of these new job zones has taken place very rapidly, without however posing a threat to the preeminence of the principal urban centers. The profile of their activities is often more specialized (for example in logistical activities, or in large commercial complexes) and less diversified than the profile of the city centers (Guérois, Le Goix, 2000). It can therefore be seen that the spatial structures of cities have become more complex, involving in particular new patterns of movement, from outskirts to outskirts, but that, up until now, they have not obliterated organizations of the center-periphery type.

As a result of a greater spreading out in residences than in jobs, the length of daily travel has been increasing : since 1975, the average distance between the home and the workplace has multiplied by two (in 1999 it was $15 \mathrm{~km}$ for active people who did not work in their residential commune). The time spent in these trips, however, has remained constant, on the order of 30 minutes per trip. This is explained by an increase in the average speed of circulation, which, according to national surveys, rose in cities from 26 to $31 \mathrm{~km} / \mathrm{h}$ between 1982 and 1994 (Orfeuil, 2001). This increase, which is linked with the intensive use of the private car and the improvement in transportation routes, is especially felt in the outlying zones (from 40 to $43 \mathrm{~km} / \mathrm{h}$ from suburbs to outskirts, from 22 to $29 \mathrm{~km} / \mathrm{h}$ from outskirts to outskirts), but it remains stable for trips made in the city centers. In its general investigation of transportation, INSEE showed that for the whole of France, an average door-to-door trip in a private car took 16 minutes, as against 36 minutes in public transportation.

\section{Interpreting Recent Trends}

The process of urban sprawl and reduction in population density at the local level began in 1968 for Paris, and from 1975 on for the other French cities, which then saw their outlying areas grow twice as rapidly as before. The awareness of peri-urbanization was thus delayed by the lack of an appropriate definition when it first appeared. Bauer and Roux's study (1976) and the Mayoux report (1979) had already warned of the magnitude of the phenomenon, but it was the results of the census of 1982 in particular that provided a more complete picture. "Renaissance des communes rurales ou nouvelle forme d'urbanisation?" asked the statisticians Boudoul and Faur (1982). The changes in the population of the cities between 1975 and 1982 were experienced by many as a break in the process of urbanization, marking a renewal of rural communes and perhaps the "end of the cities" (after the title of the work published by the sociologist Chombart de Lauwe in 1982). The higher rate of growth of the small towns in this period, the decline of the central population densities in most of the urban agglomérations, as well as the migration of populations from the city centers towards rural communes, were often interpreted as 'counterurbanization', following the description of B. Berry for North America (1976), which was taken up again in connection with Europe by T. Champion (1989).

A number of publications offered a different interpretation, however, supported by a longer-term analysis of the evolution of the spatial distribution of urban growth (Pumain, 1982 and 1983). According to this interpretation, the time-honored process of the concentration of the population in cities at the national level continued during the whole of this period (confirmations of this theory came in the censuses of the 1990s, which attested in particular to a return to growth in the metropolises). In addition, the process of urban sprawl, at the local level, certainly marked a reversal in the tendency towards increased density (a reversal that had been begun almost two centuries earlier in the central quarters of the largest cities), but which can also be interpreted, in a certain historic continuity, as an expansion of the cities into an accessible space enlarged by the use of the automobile, but relatively stable in distance-time (Bretagnolle, Paulus. Pumain, 2001). This tendency seems likely to continue, but at what rate? 
At the level of the aires urbaines, the de-concentration of the population of the city centers and suburbs towards the peri-urban zones will probably continue. The differences in demographic evolution of the city center, the suburbs and the peri-urban ring that were observed between 1990 and 1999 definitely confirm the continuation of the tendency for the populations to become spaced out in the city centers: the farther one goes from the center, the greater the average demographic growth, even if on the periphery this growth is taking place among smaller groupings of people (Table 3). The increase in the activity of women, and, as a result, the number of two-job households, contributes, in theory, to swelling the flow of inter-communal home-to-work travel. If the present tendencies in the development of urban mobility continue, the number of kilometers driven in cars in the French city-suburbs units could increase by $30 \%$ between now and 2010 (GART, 2001).

A comparison with the evolution of mobility in North America leads nevertheless to some more nuanced conclusions. While the rate of motorisation was already very high in North America in 1960, mobility progressed relatively little there between 1960 and 1990: it 'only' doubled, at a time when it was almost multiplied by three in Europe. By analogy we might expect that the evolution in the rate of motorisation and the use of the car in France could be much slower than in the past. This being said, mobility continues to increase significantly in the United States, when the country is much more motorised than the European countries. In addition, there are still an important reservoir of non-motorised population among older people, women, and especially the young (Orfeuil, 2000).

One of the principal stakes for urban mobility in the years to come is the greater role of trips from outskirts to outskirts. The growing difficulty in managing these movements is increased, furthermore, by the impact of the law establishing the 35-hour workweek on the de-synchronization of urban time. Public transportation, conceived for mass movement in dense zones, is not well adapted to the spatial and temporal scattering of urban mobility.

However, although the process of peri-urbanization continued in the $1990 \mathrm{~s}$, the results of the last census showed clearly that the slowing in this process, which had been detected in 1990, was being confirmed. The contraction in the rhythm of urban sprawl is perhaps not unrelated to the drop in French population growth. It can also be partly explained by a return to the rise in demographic growth in the city centers. The relative recovery of certain city centers had been noted in 1990, but became even more apparent in 1999, since the great majority of central communes ceased to lose inhabitants between 1990 and 1999.

Nevertheless it is not enough merely to extend the quantitative tendencies in order to draw up the future contours of urban sprawl in the cities. The factors that explain this movement have been modified because of the change in the social and political contexts, and also from analyses of the consequences of urban distribution. These transformations must be taken into account if we are to make a correct assessment of possible future situations.

\section{An Expansion Helped by Public Policies?}

As in the majority of developed countries, urban sprawl was brought in by a wave of economic expansion, and by the consecutive increase in the purchasing power of households. It also reflects the expansion of the space that is accessible every day, which is linked to the increase in the use of the private car. In this sense, the date of the appearance of the process in France corresponds to the relative situation of the country in the post-war movement of urbanization and modernization, which could be described simply as a spatial diffusion begun in Northern Europe that eventually took hold in Southern Europe. The intensity of the process in France (a theory that remains to be proven when the possibilities for European comparison have improved) should nonetheless be explicable by reference to particular conditions. The general weakness in density, resulting in weaker property values and a greater availability of space, is a likely factor. The effect of public policies that have accompanied the movement is another plausible explanation.

\section{The Individual House and Housing Policy}

State policies designed to solve the problem of housing shortages in the context of post-war reconstruction and the succeeding phase of unprecedented demographic growth (baby boom, massive rural exodus, and then at the start of the 1960s, the reintegration of two million people from Algeria), were initially expressed in the building of large collective structures, between 1950 and 1970, favored by the institution in 1958 of the Zones d'Urbanisation 
Prioritaires (ZUP). The marked preference from this period on for the acquisition of property for individual housing, the rejection of the large collective groupings by the middle classes, and modification in family structures, from the end of the 1960s, inspired the first waves of building of individual housing estates. Motivations offered as reasons for moving are related much more to conditions of housing (surface space, cost, the desire to change from renting to property ownership, and from the collective to the individual), than to a search for the advantages of a rural environment (Orfeuil, 2000).

These 'spontaneous' tendencies were certainly increased by national policies. The Real Estate law of 1967, with the ZAC procedure (Zone d'Aménagement Concerté - Collaborative Development Zone) provided greater flexibility for the establishment of housing estates with individual houses. In particular, it was the law of 1977 on the financing of public housing, substituting for 'aid towards stones' an 'aid to persons', by guaranteeing loans for the acquisition of property for low-income households, which promoted the extension of the cities. Thus in the beginning of the $1980 \mathrm{~s}, 40 \%$ of new constructions were destined for households that were benefiting from assistance.

\section{From 'all cars' to public transportation}

Although the evolution of mobility has been comparable to the development observed in other European countries, the French State has been particularly active in the construction of infrastructures favorable to the car. In the period from 1960 to 1970, the dominant policy was to adapt the city to the car. These years were therefore also marked by the significant size of investments in motorways and expressway intended to open up territories at different levels. The length of the network of motorways multiplied by 2.5 between 1975 and 1990 (from 2,700 km to $6,800 \mathrm{~km}$ ), chiefly influenced by a policy aimed towards 'catching up'. The great inter-city motorway networks followed a logic of settlement that favored inter-city automobile traffic, with roads often set up as close as possible to towns or villages, if not actually passing through them. Certain expressways therefore opened vast spaces to periurbanization, like Route Nationale 20 to the south of Paris, along which housing estates stretch to the south of Essonne, from Arpajon to Montléry.

Beginning in the 1970s, several cities came up with the idea of resisting the invasion of the automobile through a more widespread use of pedestrian zones, as well as the introduction of public transportation in bus lanes, and succeeded in slowing down the growth of intra-urban traffic. But in the same period, in early 1970, the appearance of ring roads (beltways) to 'protect the city', as well as parking facilities provided for employees of businesses, contributed to a considerable increase in urban sprawl.

\section{Several Attempts at Regulation}

Considered overall, the authorities have not elaborated a general policy for or against the tendency towards urban sprawl. However, many institutional arrangements have converged towards, and even encouraged, urban sprawl, or at least a certain policy of laissez faire. The multiplicity of different works agencies (Commune, State, Public Establishments of Inter-community Cooperation), objectives, perimeters, time frames for planning and implementation, have led to an often fragmented approach to the spatial development of cities. For a long time, the absence of a single professional tax has led communes to practice escalation to attract businesses, and favored the nibbling away of the countryside by the city (Sueur, 1999). Unlike the practices in Germany, England and the Netherlands, the policies for urbanism and transportation are relatively independent in France; there are no constraints on transportation services for the locations of most activities.

Nevertheless, an intention to control urban sprawl has been expressed in two special areas: a program of urbanism on a grand scale, in the case of the new towns of the Paris region, and a series of 'lois-cadres', on the environment, on urban transportation and on regulations for commercial facilities.

Through the policy for the new towns, the State has encouraged the control of the spread of Paris and its suburbs. Included in the planning scheme for the development and urbanism of the Paris region of 1965 (and thus adopted later than in other European cities), this policy led to the creation of five new towns located near the Paris agglomération, at least $30 \mathrm{~km}$ from the center of the capital, without creating a green belt. By participating in this exceptional urbanism project, the State affirmed a strategic choice for implementing an urban polycentrism. This choice seemed motivated by "a restrictive discourse to counter the environment of the housing estate", with the 
intention of "counteracting the radio-concentric tendencies of spontaneous urban development" (Pumain, 1997), reinforced by encouragements to produce high urban densities. From this perspective, the new towns contributed in part to organizing the expansion of the city and suburbs of Paris. Since 1975, they have absorbed more than half of the demographic growth in Paris, and have acquired commercial facilities which make of them, or at least make four of them, centers that polarize the surrounding suburbs. They have not however significantly limited the urbanization of Francilian green spaces. The Zones Naturelles d'Equilibre (Zones of Natural Stability) in Ile-de-France were intended to create buffer zones in the spaces between the five new towns, to protect agriculture and the forests, but in the absence of legal directives and specific regulations (in particular, the directive cannot be used as evidence against a third party), their impact has remained limited.

Different types of 'lois-cadres' have contributed directly or indirectly to controlling urban sprawl. In encouraging the protection of vulnerable spaces in relation to the extension of cities, several laws voted in 1985 provided specific procedures for protected environmental zones and for certain especially sensitive zones like coastal regions or mountains. In addition, the plans de déplacements urbains (PDU) were set up to implement urban transportation policies that were less favorable to the automobile and more respectful of the environment of the cities. Created in 1983 by the law covering the direction of domestic transportation, they served primarily to cover projects of public transportation in the city centers, without a close link to land-occupancy projects and planning schemes. Laws governing high-volume trade - which has often generated moves to the outskirts of cities - are another aspect of these 'lois-cadres': they were first designed to protect existing businesses (the Royer law), and then, in the beginning of the $1990 \mathrm{~s}$, directed also towards organizing the commercial framework of the urban periphery (the Raffarin law), by bringing in more and more services.

In spite of these arrangements, after the passage of the 1982-1983 decentralization laws ${ }^{1}$, the major task of controlling urbanization - through the provision of building permits - became the prerogative of the local communes. In the end it is the mayors that have the power of decision concerning whether or not extend building in their territory. The different instruments can be argued in theory, but do not all have an obligatory character.

\section{A New Institutional Order for Regulating Urban Sprawl}

In the space of two years, between 1999 and 2000, the passage of two laws on intercommunality and the adoption of the law on 'Solidarity and Urban Renewal' have revamped the institutional framework of the government of the cities. In reinforcing the intercommunal level and raising the control of peripheral urbanization to become the major objective of urban 'renewal', this new legislative system is moving in the direction of a more coherent and more efficient management of urban sprawl at the level of the agglomération.

From 'Communal Explosion' to Communities of City and Suburbs, and Urban Communities (1999)

The laws known as the Voynet $^{2}$ (26 June 1999) and Chevènement ${ }^{3}$ (12 July 1999) laws have strengthened the emergence of an authority for agglomérations in going farther than previous efforts towards supra-communal management. They have further developed the means, competence and fiscal resources necessary for putting into place an integrated strategy of development.

Two new structures were created by the law of 12 July 1999: les communautés d'agglomération and the communautés urbaines. The communautés d'agglomération, which replace the districts and communities of communes, form a group of communes in single block, numbering at least 50,000 inhabitants around a city centre of more than 15,000 inhabitants. The communautés urbaines are reserved for the largest cities, and must include at least 500,000 inhabitants. Since the end of 1999, fifty communautés d'agglommération and two communautés urbaines have been created, and thirty more communautés d'agglomération are planned.

\footnotetext{
${ }^{1}$ Before these laws existed, building permits were delivered by the Préfecture of the department, the authority representing the State at the local level.

${ }^{2}$ Loi d'Orientation sur l'Aménagement et le Développement Durable du Territoire (L.O.A.D.D.T.)

${ }^{3}$ Loi de simplification et de modernisation administrative du territoire français
} 
Among the numerous powers attributed to these structures, several, such as the development of space or the management of transportation and the habitat, are directly linked to the question of urban sprawl and its regulation. The principal innovations brought in by this law are found in the creation of two financial levers: the adoption of the single professional tax, and the attribution of an overall allocation for functioning. In addition, the communautés d'agglomération and the communautés urbaines are the principal representatives and beneficiaries of the Stateregion planning contracts within the framework of the agglomeration contracts. These contracts are defined in the framework of the agglomération projects encouraged by the law of 25 June 1999. The creation of communities, projects and contracts for agglomérations could thus ratify the recognition of the level of the agglomération as a territory of consultation, management and decision.

\section{The Solidarity and Urban Renewal Law and the Limitation of Peripheral Urbanisation}

The SRU law, adopted in December 2000, which is part and parcel of the general struggle against urban explosion, and the implementation of the right to housing, extends the spirit of this legislative operation by encouraging a better intercommunal coordination. More specifically, it also declares that one of its objectives is the limitation of peripheral urbanization. The awareness of the problem of urban sprawl is expressed in the modification of the documents of urbanism in the direction of a closer coordination between policies of urbanism, the habitat and travel, and in new local policies related to public transportation.

\section{Modification in the documents concerning urbanism}

Adjustments have been planned to modify the documents related to urbanism established by the real estate law of 1967. The Local Plan for Urbanism (PLU) will replace the POS at the communal level at the time of its revision. In the spirit of the SRU law, the integration of new measures should enable the communes to favor urban renewal (to 'reconstruct the city on the city'), and to control peripheral extension, for example in the form of fiscal measures: taxes for exceeding the maximum ceilings of density are eliminated in order not to discourage certain projects for urban recomposition; in addition, the inclusive valuations used to compute the local tax for facilities are corrected to help in the construction of collective housing.

The Scheme for Territorial Coherence (SCOT) is to replace the Schema Directeur (Guiding Scheme). Like the Guiding Schemes, the Schemes for Territorial Coherence will provide specifications at the level of the agglomération for overall objectives for development and urbanism, taking into account the policies for the habitat, for leisure activities, for services and infrastructures. Within the framework of the most recent reforms concerning intercommunality, they fit between the plan for agglomérations, of which they are the spatial extension, and the contract for agglomération that constitutes one of the means of their implementation. They are nonetheless distinguished from the Guiding Schemes by their more constraining character. Indeed, in the absence of a SCOT, the future zones of urbanization of the communes defined in the local plan for urbanism could not be opened to urbanization. Within this framework, the communes would therefore have less freedom to urbanise their territory.

\section{The Integration of urban policies}

The SRU law aims to make the urban policies more coherent with each other. This objective is achieved in part though the Scheme of Territorial Coherence, which, more than the Guiding Schemes, requires the local professional bodies to agree on a project of urbanism. In addition, this intention is expressed in the strengthening of the ties between the documents of urban planning and the documents concerning travel, in particular public transportation. Although transportation and its coordination with urbanism are the extension for which the SRU law grants the greatest means, in a more general way the law also encourages a greater coherence in local urban policies concerning habitat, urban planning, economic development and commercial siting: in the same way as the Plans de Déplacements Urbains, the Local Habitat Programs and Schemes for Commercial Development should be compatible with these documents, and not just 'take them into account', as was the case with the POSes.

If policies for limiting the place of the automobile in the city are less repressive in France than in other countries, for example in Italy (Fouchier, 1998), France remains the country of the European Union which, in both the long and the short term, is expecting the most from the structural consequences of an investment in a public transportation policy. The re-launching of the Plans de Déplacements Urbains (Transport Planning within the Cities) (PDU) is emerging as a driving force in the policy of limiting automobiles in the cities. 


\section{The 'Plans de Déplacements Urbains'}

The Plans de Déplacement Urbains are key documents for the regulation of urban sprawl in France, with their objective of contributing to the lessening of automobile traffic (Loi sur l'air, 1996) (Clean Air Law). This objective is pursued through a whole arsenal of means including the development of public transportation, the search for less polluting means of transportation, the development of the network of roads, the organization of parking, the reduction of the impact of transports and the delivery of goods, encouragements to the personnel of businesses and professional bodies to use public transportation and take advantage of car-pools, etc.

The Plans de Déplacements Urbains were created in 1983, but it was the loi sur l'air of 1996 that gave them a 'second wind' in making them obligatory for agglomérations of more than 100,000 inhabitants. In addition, the law specifies that the POSes and the ZACs should take into account 'the orientations of the PDUs' at the time of the revision of the POSes. Further, the SRU law gives validity to the PDUs by encouraging the coherent mutual development of the policies of transportation and urbanism. In this law, the PDUs are described as the 'transportation extension' of the Scheme of Territorial Coherence. On April 30 2001, in the 58 agglomérations with more than 100,000 inhabitants, 45 completed PDUs were counted (GART, 2001). Most of them were aiming for a drop in the modal role of cars in travel, with Lyon counting on a drop of 3 points between now and 2005, Toulouse on a drop of 5 points by 2008 .

\section{Public Transportation at the local level}

To offer an alternative solution to the private car and to reduce traffic congestion by means of the administration of roads are the primary arguments for the development of local public transportation. The investments of the professional bodies (municipalities and regions) are considerable: they have been estimated at 10 billion euros from now until 2010 (GART, 2001). In the next few years, two-thirds of the budget of the Ile-de-France region will go to public transportation. The reappearance of urban tramways is one of the most spectacular consequences of this policy: Saint-Etienne had preserved its tramways, Nantes and Grenoble were among the first to reintroduce them, in 1985 and 1987, and since then, Rouen, Strasbourg, Saint-Denis to the North of Paris, Montpellier and Orléans have all opened new lines. Lyon and Marseille have chosen the métro. Lille, Toulouse and Rennes have opted for the VAL. Many other projects are under construction (Beaucire et Lebreton, 2000). Added to these expensive measures, which are reserved for the most densely-populated cities, but appreciated by the public for their contribution to the protection of the environment and the quality of life in the city, are other solutions, such as the special lanes reserved for the circulation of buses, or flexible systems using new techniques of communication to serve the least dense peripheral areas. In 1998, almost all of the PDUs considered the development of public transportation to be a planning priority (GART, 2001).

\section{Parking and urban tollbooths}

Since 1967, the Plans d'Occupation des Sols (Plans for Land Use) have included prescriptions determining the minimal norms for parking places in new areas of construction. With the loi sur l'air (1996), action related to urban parking figures in the texts as a principal element in policies for travel and movement, but in practice it is the forgotten daughter of the Plans de Déplacements Urbains, which are more oriented towards public transportation in general and tramways in particular (GART, 2001). Recently the SRU law contributed to strengthening the control of parking, changing the Plans Locaux d'Urbanisme (Local Plans for Urbanism) by replacing the minimal norms for parking places established in 1967 with maximal norms. It also encourages the practice of a positive discrimination among users (favoring residents, dissuading commuters), and in this perspective encourages businesses to promote home-to-work travel by other means than the car (mobility plans). In addition, the provisions of the SRU law prescribe more specifically than the Loi sur l'air (the Clean Air Law) the framework within which the management of public parking and the norms planned for private parking (in particular for goods delivery) should be treated in the urbanism documents.

The establishment of urban tolls is conceived of as a more restrictive instrument for regulating travel than as an action related to parking, but also as a possible source of financing to meet the need for investment for transportation. The experience of four metropolises: Marseille, Toulouse, Paris and Lyon, has shown in what conditions this solution is acceptable to the public. Tolls on new infrastructures have not raised major opposition 
when introduced with a concern for transparence and communication: in Marseille, the Prado-Carénage Tunnel, the first urban construction with tolls, opened in 1993, crosses the city to link two motorways. In Paris, the tolls on the A14, which links the business quarter of La Défense to Orgeval (Normandy) has been accepted in spite of its rather high cost (5.6 euros), and remains free for those who use carpools during the week. In Lyon, the toll on the northern section of the ring road (ex-TEO) was only accepted after a boycott that led to a lowering of the price, which had been considered too high at the outset. On the other hand, the establishment of tollbooths on a former section of the southern suburbs of Toulouse ended in failure, and free passage was restored for the use of the old route.

Beyond these several experiences, discussions have begun on projects for more widespread use of tolls, that is, tolls that are not limited to new infrastructures, but delimit a recognizable space (connector-roads) or are applied to a whole network of expressways, but for the time being, tolls for the new infrastructures are the only ones allowed within the French legal system.

\section{Conclusion}

The process of urban sprawl is tied to the question of the core city that endures in time, which will probably dominate discussions of urban planning and public transportation in the countries of the European Union throughout the coming decades. Sustainable development remains a vague and very general concept which, when applied to cities, raises questions both of economic efficiency (including that of productive capital, infrastructures and technologies), ecological performance (natural capital, resources, biological equilibrium) and social development (cultural capital, authorities, common values). The system of the relations and the actors involved is so complex that we should refrain from recommending any policy at all, before we have developed thorough comparative analyses (Bertuglia et al., 1998).

The spatial extension of the cities into neighboring rural spaces is an essential characteristic of the urbanization of the last thirty years. Global in scope (Dureau et al., 2000), this process is doubtless linked to the rapid spread of certain technologies - in particular those related to individual means of transportation —often associated with the rise in the standard of living and the globalization of many economic and cultural standards. Although the effects of urban spread were felt earlier, beginning in the 1950's, in North America, it would be too simplistic to explain this new way of building cities and organizing urban life by adopting a morphological model and an urban life-style that originated in the United States. Several urban traditions coexist in the world, each one with a different way of reacting to the necessary adoption of such innovations. It is likely that the European model of urbanization therefore constitutes an alternative to the American model. This is not only a matter of path dependency in a complex evolution but also of persistent differences in the values of key-parameters. On the list of possibly relevant ones are probably the residential mobility rate, the rate of commuting, the speed of intra-urban circulation, the relative level of selling taxes, urban planning rules, the size of administrative units for counting population, as well as cultural values and attitudes towards urbanization.

In this respect, the presentation of the French case calls for caution. The state of our knowledge of the subject is still in its early stages. Systems for measuring the spatial extension of cities have recently been improved, and now make it possible to observe the morphological characteristics of urban sprawl over a period of fifty years. Nevertheless, because of the lack of sufficiently comparable concepts and statistical definitions for the European cities (Cattan et al., 1994, Pumain et Saint-Julien, 1996), it remains difficult to relativize the French case according to the observed tendencies in other European countries. At the very least, we can advance the idea that urban spread has developed later in France than in the countries of Northern Europe, but earlier than in Spain and Italy. Furthermore, the relatively marked extension of the cities should be considered in relation to the low average density of the country and the development of individual property.

The fact that this chronology recalls a process of spatial distribution leads to the idea that these same demographic, sociological and economic transformations could account for the spatial expansion of the cities from one country to another. An attentive reading of the interpretations given in the literature shows, however, that several factors specific to French society and territory interfere with the general process, and are in considerable measure responsible for a style of peri-urbanization. Beyond a marked preference for the individual house (which is to be associated with the recent rural past of a part of French society), the intervention of the State, through a housing policy that has favored new construction, doubtless played a determinant role in the growth of the peri- 
urban fringes. France nonetheless brings together two features which elsewhere would involve a paradox: although in comparison with the cities of Northern Europe, the use of the individual car has been encouraged in France, the city centers have continued to be strongly promoted. For some time, since before the very concept of the sustainable city emerged, they have been the object of protection and renovation, measures that continue to attract the population and also to inspire economic activity. The French case in addition is characterized by the fact that this policy, which has been applied in most of the cities, has borne fruit without being strongly supported by State intervention, and this in spite of the fragmentation of political decisions at the local level and a relatively nonrestrictive planning system.

For all that, there is no general consensus in France around the question of urban sprawl. The consequences of this process have been assessed in very different ways from one expert to another (Chalas, 2001), and they are still the subject of debate.

\section{References}

Bauer, G. and Roux, J.-M. (1976), La Rurbanisation ou la ville éparpillée, Seuil, Paris.

Beaucire, F. and Lebreton, J., (2000), Transports publics et gouvernance urbaine, Editions Milan, Toulouse.

Berry, B.J.L. (1976), Counterurbanization. Sage, New York.

Bertuglia, C.S. Bianchi, G. and Mela, A. (eds) (1998), The City and Its Sciences, Physica Verlag, Heidelberg.

Bessy-Pietry, P. Julien, P. and Royer, J.F. (2000), 'De nouveaux périmètres urbains pour la France de l'an 2000 ”, in Mattei, Pumain (eds), Données Urbaines 3, Anthropos, Paris, pp. 9-17.

Boudoul, J. and Faur, J.P. (1982), 'Renaissance des communes rurales ou nouvelle forme d'urbanisation?', Economie et Statistiques, INSEE, ${ }^{\circ} 149$.

Bretagnolle, A. and Paulus, F. (2001), 'Time and space scales for measuring urban growth', Cybergeo, 219, 12 p. (http://www.cybergeo.presse.fr)

Cattan, N. Pumain, D. Rozenblat, C. and Saint-Julien, T. (1999), Le système des villes européennes, Anthropos, Paris (first edition 1994).

Champion, A. (1989), Urbanisation and counterurbanisation. Arnold, London.

Chalas, Y. (2001), L'invention de la Ville, Anthropos, Paris.

Dureau, F. Dupont, V. Lelièvre, E. Lévy, J.P. and Lulle, T. (2000), Métropoles en mouvement, une comparaison internationale, Anthropos, Paris.

ESPD-European Spatial Development Perspective (1999), Towards Balanced and Sustainable Development of the Territory of the European Union, European Commission, Luxemburg.

Fouchier, V. (1998), Les Densités urbaines et le développement durable. Le cas de l'Ile-de-France et des villes nouvelles, Editions du Secrétariat Général du Groupe Central des Villes Nouvelles, Paris.

GART (Groupement des autorités responsables de transport) (2001), Plans de Déplacements Urbains, des intentions à l'action. Paris.

Guérois, M. and Le Goix, R. (2000), «La multipolarité dans les espaces métropolitains : Paris, Lyon, Marseille et Lille », in Mattei, Pumain (eds), Données Urbaines 3, Anthropos, Paris, pp.235-249.

Guérois, M. and Paulus, F. (2001), 'Commune centre, agglomération, aire urbaine : quelle pertinence pour l'étude des villes ?', Cybergeo, 212, 18 p. (http://www.cybergeo.presse.fr)

Guérois, M. and Pumain ,D. (2002), Urban Sprawl in France (1950-2000), Franco Angeli, Milano.

Julien, Ph. (2001), Des nomenclatures spatiales françaises : application à la mesure de l'urbanisation en France métropolitaine. $\mathrm{PhD}$ thesis, Université de Toulouse-le-Mirail.

Lainé, F. (2000), «Périurbanisation des activités économiques et mouvements d'emploi des établissements », in Mattei, Pumain (eds), Données Urbaines 3, Anthropos, Paris, pp. 251-260.

Mayoux, J. (1979), Demain l'espace. Rapport de la mission d'étude sur l'habitat individuel péri-urbain, Paris : La Documentation Française, $154 \mathrm{p}$.

Orfeuil, J.P. (2000), Stratégies de localisation. Ménages et services dans l'espace urbain, Paris : La Documentation Française, $75 \mathrm{p}$.

Orfeuil, J.P. (2001), L'Evolution de la mobilité quotidienne. Comprendre les dynamiques, éclairer les controverses, Synthèse INRETS n ${ }^{\circ} 37,146 \mathrm{p}$.

Paulus, F. (2002), Evolution of the economic structure of the French Urban System, 1954-1999. University of Paris I, doctorate thesis in preparation. 
Paulus, F. and Pumain, D. (2002), Répartition de la croissance dans le système des villes françaises. Revue d'Economie Régionale et Urbaine, 1, 35-48.

Pumain, D. (1982), La dynamique des villes. Paris, Economica.

Pumain, D. (1983), Déconcentration urbaine, Population et Sociétés, INED, n 166.

Pumain, D. (2000), Settlement systems in the evolution. Geografiska Annaler, 82B, 2, 73-87.

Pumain, D. and Saint-Julien, T. (1991), The statistical concept of towns and cities in Europe, Eurostat, Luxembourg, $72 \mathrm{p}$.

Pumain, D. and Saint-Julien, T. (eds) (1996), Urban Networks in Europe, Paris: John Libbey/INED, Congresses and colloquia $\mathrm{n}^{\circ} 15,252 \mathrm{p}$.

SPESP (Study Programme on European Spatial Planning), (2001), Final Report, Bonn: Federal Office for Building and Regional Planning.

Sueur, J.P. (1999), Changer la ville, Paris : Editions Odile Jacob, 215 p. 